\title{
Pembentukan Kalimat Pasif Bahasa Jepang: Studi Kasus Pembelajaran Kalimat Pasif Bahasa Jepang Pada Pembelajar Indonesia
}

\author{
Rani Arfianty', Adriana Hasibuan² \\ Faculty of Cultural Sciences, Universitas Sumatera Utara \\ Rani.arfianty@usu.ac.id \\ Faculty of Cultural Sciences, Universitas Sumatera Utara \\ adrianahasibuanoo@gmail.com
}

\begin{abstract}
This Study Aims To Analyze The Errors In The Construction Of Japanese Passive Sentence. This Research Involves Indonesian Japanese Language Students $4^{\text {th }}$ Semester. The Research In 200 Words. Quantitative And Qualitative Methods Are Used Based On The Error Establishment Definition Of Japanese Passive Sentence, Ichikawa (2005). The Research Result Shows The Students Make Mistake In Changing The Japanese Passive Verb Form By 53\%, The Error In Practice Selection As Much As 24\% The Error In The Subject Structuring And Object Complement 18\% And Error In Sentence Formation If Yari-Morai (Giving-Taking) As Much As 5\%.

The Error In Changing The Japanese Passive Verb Form Is Caused By A Lack Of Practice And Understanding Of Japanese Passive Forms. Error In Particle Selection Is Caused By Negative Transfer Factor. The Lack Of Students 'Understanding Of The Formation Of Japanese Passive Sentences Causes Learners Tend To Arrange Subjects And Principals' Objects In Japanese Passive Sentences Following The Indonesian Passive Sentence Arrangement Rules. The Results Of This Study Can Provide An Overview For Japanese Language Teachers, Especially The Acquisition Of Learning Japanese Sentence Passive Among Indonesian Students To Be Able To Make A Variety Of Creative Teaching.
\end{abstract}

Keywords: Japanese Passive Sentence, Error Establishment, Indonesia Japanese Learner, Selection Error.

Intisari

Penelitian Ini Bertujuan Untuk Menganalisis Kesalahan Dalam Membentuk Kalimat Pasif Bahasa Jepang. Penelitian Ini Melibatkan Pembelajar Bahasa Jepang Indonesia Semester IV di USU. Sampel Penelitian Ini Adalah Karangan Berupa Kalimat Pasif Berbahasa Indonesia Dalam 200 Perkataan. Metode Kuantitatif Dan Kualitatif Digunakan Berdasarkan Defenisi Kesalahan Pembentukan Kalimat Pasif Bahasa Jepang Ichikawa (2005). Hasil Analisis Penelitian Menunjukkan Pembelajar Melakukan Kesalahan Dalam Mengubah Bentuk Verba Pasif Bahasa Jepang Sebanyak 53\%, Kesalahan Dalam Pemilihan Partikel Sebanyak 24\%, Kesalahan Dalam Penyusunan Subjek Dan Objek Pelaku Sebanyak 18\% Kesalahan Dan Kesalahan Dalam Membentuk Kalimat Yari-Morai (MemberiMenerima) Sebanyak 5\%. Kesalahan Di Dalam Mengubah Bentuk Verba Pasif Bahasa Jepang Disebabkan Oleh Kurangnya Latihan Dan Kurangnya Pemahaman Pembelajar Mengenai Bentuk Pasif Bahasa Jepang. Kesalahan Dalam Pemilihan Partikel Disebabkan Oleh Faktor Negatif Transfer. Kurangnya Pemahaman Pembelajar Terhadap Pembentukan Kalimat Pasif Bahasa Jepang Menyebabkan Pembelajar Cenderung Untuk Menyusun Subjek Dan Objek Pelaku Dalam Kalimat Pasif Bahasa Jepang Memenuhi Aturan Penyusunan Kalimat Pasif Bahasa Indonesia. Hasil Penelitian Ini Dapat Memberikan Gambaran Bagi Pengajar Bahasa Jepang Khususnya Mengenai Pemerolehan Pembelajaran Kalimat Pasif Bahasa Jepang Di Kalangan Pembelajar Indonesia Hingga Dapat Membuat Variasi Pengajaran Yang Lebih Kreatif Lagi.

Kata Kunci: Kalimat Pasif Bahasa Jepang, Kesalahan Pembentukan, Pembelajar Bahasa Jepang, Kesalahan Pemilihan 


\section{Pendahuluan}

Penelitian mengenai pembelajaran bahasa asing sebagai bahasa kedua oleh peneliti bahasa mengungkapkan adanya kesalahan-kesalahan dalam penggunaan bahasa kedua oleh pembelajar. Ozeki (2010), menyebutkan terdapat dua jenis kesalahan yang dilakukan oleh pembelajar bahasa Jepang. Pertama, kesalahan inter-lingual (inter-lingual error), yaitu kesalahan yang disebabkan gangguan dari bahasa ibu dikarenakan adanya perbedaan sistem aturan ketatabahasaan di antara kedua bahasa. Kedua ialah kesalahan intra-lingual (intralingual error), yaitu kesalahan yang terjadi tidak ada kaitannya dengan pengaruh bahasa ibu, tetapi, disebutkan bahwa kesalahan terjadi semata-mata disebabkan oleh proses pengembangan (developmental process).

Gangguan bahasa ibu (cross linguistic influence), juga diketahui sebagai pemindahan bahasa (language transfer) (Odlin, h.1989; Ozeki, 2005). Odlin (1989) menyebutkan bahwa terjadinya pemindahan bahasa merupakan akibat daripada persamaan dan perbedaan di antara bahasa kedua dan bahasa asing lain yang telah dipembelajari sebelumnya. Jika di antara bahasa ibu dan bahasa kedua mempunyai beberapa persamaan baik di dalam perkataan maupun tata bahasanya, maka pemindahan positif cenderung akan terjadi. Seperti halnya bahasa Indonesia dan bahasa Malaysia dalam rumpun Melayu, keduanya memiliki persamaan pada banyak kosakata bahkan tata bahasa. Adanya beberapa persamaan pada kosakata dan tata bahasa di antara bahasa Indonesia dan bahasa Malaysia ini, cenderung menyebabkan terjadinya pemindahan positif ketika orang Indonesia berusaha untuk menggunakan dan berbicara dalam bahasa Malaysia ataupun orang Malaysia yang mencoba untuk berbicara dalam bahasa Indonesia.

Namun, jika bahasa ibu pembelajar berbeda dengan sistem aturan tata bahasa bahasa kedua, hal ini dapat memungkinkan terjadinya pemindahan negatif. Contohnya, pada bahasa Indonesia dan bahasa Jepang. Adanya perubahan bentuk verba berdasarkan pola kalimat dan keterangan waktunya di dalam aturan tata bahasa bahasa Jepang telah membingungkan pembelajar Indonesia hingga menghadapi kesulitan ketika mengaplikasikan dan menerjemahkan kalimat bahasa Indonesia ke dalam kalimat bahasa Jepang, karena perubahan bentuk verba Jurnal Lingua Applicata Volume 2 Nomor 1 September 2018 
ini tidak ditemui di dalam aturan tata bahasa bahasa Indonesia. Seperti terlihat pada contoh kalimat (1) yang diambil dari kalimat yang dibuat oleh pembelajar bahasa Jepang:

(1). Saya dibelikan ayah mainan.

Watashi - wa chichi - ni - omocha - o kawarasemashita.

Saya-partikel-ayah-partikel-

mainan-partikel-kawarasemashita

Penerjemahan kalimat bahasa Indonesia ke dalam kalimat bahasa Jepang pada contoh kalimat (1) di atas adalah kalimat yang dihasilkan oleh pembelajar ketika diminta untuk menerjemahkan kalimat 'saya dibelikan ayah mainan'. Kalimat bahasa Indonesia pada contoh (1) yang diterjemahkan ke dalam kalimat pasif bahasa Jepang mungkin dapat dipahami maknanya, tetapi, kalimat terjemahan tersebut tidak sesuai dengan aturan tata bahasa bahasa Jepang. Pembelajar cenderung terpengaruh dengan awalan -di pada verba bahasa Indonesia yang menunjukkan bahwa kalimat tersebut adalah kalimat pasif. Kalimat bahasa Indonesia tersebut menunjukkan kalimat pasif dan, bila ditelaah lebih lanjut, kalimat 'saya dibelikan mainan oleh ayah' menunjukkan bahwa subjek menerima sesuatu barang, yaitu mainan dari ayahnya dan ia merasa senang. Justru, bentuk kalimat ini menunjukkan makna rasa terima kasih dan penghargaan kepada orang lain yang di dalam tata bahasa bahasa Jepang menggunakan bentuk yari-morai (memberi dan menerima), bukan kalimat pasif yang menunjukkan mendapat suatu perlakuan ataupun perbuatan dari orang.

Berdasarkan kalimat bahasa Jepang yang dibuat oleh pembelajar untuk menerjemahkan kalimat (1) dapat dilihat bahwa pembelajar cenderung untuk menerjemahkan kata per kata di dalam kalimat bahasa Indonesia ke dalam bahasa Jepang, tetapi, mengabaikan aturan penggunaan verba pasif di dalam bahasa Jepang hingga menyebabkan timbulnya negatif transfer.

Bentuk aktifitas penerjemahan kata per kata dari bahasa Jepang ke dalam perkataan yang mempunyai arti yang sama ataupun mirip ke dalam bahasa Indonesia seperti yang dilakukan oleh pembelajar Indonesia, telah disebutkan oleh Harmer (2001), di dalam bukunya, yaitu, aktifitas penerjemahan merupakan hal yang tidak dapat dihindari di dalam pembelajaran bahasa asing. Menurut Moentaha (2006), teori terjemahan mempunyai hubungan langsung dengan linguistik perbandingan bahasa. 
Penelitian mengenai pengajaran bahasa asing dengan melibatkan teori terjemahan dapat mengatasi permasalahan interferensi ataupun gangguan di dalam pembelajaran bahasa asing.

Penelitian ini membicarakan tentang kesulitan yang dihadapi serta kesalahan yang dilakukan oleh pembelajar bahasa Jepang ketika menerjemahkan kalimat pasif berbahasa Indonesia ke dalam kalimat pasif bahasa Jepang. Perbedaan aturan tata bahasa bahasa Jepang dengan aturan tata bahasa bahasa Indonesia menyebabkan terjadinya pemindahan positif juga sekaligus pemindahan negatif dalam pembentukan kalimat pasif yang tepat ke dalam bahasa Jepang ketika menerjemahkan kalimat pasif bahasa Indonesia ke dalam kalimat pasif bahasa Jepang. Adanya perbedaan aturan pembentukan dan penggunaan yang kentara mengenai kalimat pasif bahasa Jepang dengan kalimat pasif bahasa Indonesia diduga menjadi penyebab timbulnya kesalahan dalam penggunaan dan pembentukan kalimat pasif bahasa Jepang. Di antara perbedaannya adalah, di dalam tata aturan pembentukan kalimat pasif bahasa Jepang, kata yang menunjukkan verba di dalam kalimat bahasa Jepang perlu diubah ke dalam bentuk pasif rareru yang dalam bahasa Indonesia biasanya berupa kata kerja dengan awalan -di. Kemudian, kalimat pasif bahasa Jepang juga memerlukan partikel tertentu sebagai penanda subjek (pelaku) perbuatan dan sebagai penanda seseorang (objek) yang menerima suatu perlakuan dari subjek, yang mana aturan pembentukan ini tidak tertera di dalam aturan pembentukan kalimat pasif bahasa Indonesia. Hal ini tentu saja menjadi hambatan bagi pembelajar dalam menguasai bahasa Jepang yang tepat, sebagaimana disebutkan oleh Yoshikawa (1997). Untuk itu, yang menjadi pertanyaan pada penelitian ini adalah:

1. Bagaimanakah pembelajar Indonesia mengaplikasikan kalimat pasif bahasa Jepang?

2. Apakah bentuk-bentuk kesalahan yang dilakukan oleh pembelajar ketika mengaplikasikan kalimat pasif bahasa Jepang?

Objektif penelitian ini adalah untuk mendiskripsikan kesalahan dan menganalisis bentuk-bentuk kesalahan dalam membentuk kalimat pasif bahasa Jepang yang dilakukan oleh pembelajar bahasa Jepang di Indonesia. 
Penelitian ini hanya menganalisis kesalahan dan bentuk-bentuk kesalahan yang muncul dalam aktifitas penerjemahan kalimat-kalimat bentuk pasif dalam bahasa Indonesia ke dalam kalimat pasif bahasa Jepang yang dilakukan oleh pembelajar bahasa Jepang di Indonesia.

Di antara hambatan utama bagi pembelajar dalam mempembelajari bahasa Jepang disebutkan adalah; adanya gangguan dari bahasa ibu, dan dari bahasa asing lain yang telah dipembelajari sebelumnya; ataupun kesalahan dalam memahami tata bahasa bahasa Jepang itu sendiri (Yoshikawa: 1997). Oleh karena itu, Yoshikawa (1997) menyebutkan penelitian mengenai perbandingan di antara bahasa ibu dan bahasa kedua baik dilakukan untuk memastikan ciri khas dari bahasa kedua yang tidak ada ditemui pada bahasa ibu. Sedangkan Hama (2005), mendapati pembelajar melakukan kesalahan ketika membuat karangan berbahasa Jepang. Beliau mengatakan kesalahan yang muncul dalam karangan pembelajar tersebut bukan hanya semata-mata disebabkan oleh gangguan dari bahasa ibu pembelajar tersebut, tetapi, turut disebabkan oleh teknik pengajaran bahasa kedua yang kurang sesuai dengan pembelajar bahasa Jepang tersebut.

Penelitian mengenai kalimat pasif bahasa Jepang cukup mendapat perhatian di kalangan peneliti bahasa Jepang. Risda (2009), mengatakan kesalahan yang dilakukan oleh pembelajar Indonesia ketika menggunakan bentuk pasif bahasa Jepang di antaranya adalah disebabkan oleh pengalaman pembelajar bahasa Jepang yang terdahulu. Selain itu, pembelajar juga cenderung untuk menukar kalimat pasif dalam bahasa ibu ke dalam kalimat aktif bahasa Jepang.

Mengenai kalimat pasif di dalam bahasa Jepang, Ichikawa (2005), mengkelaskan kalimat pasif bahasa Jepang kepada 2 kelompok besar, yaitu: kalimat pasif langsung dan kalimat pasif tidak langsung. Lebih lanjut, Ichikawa menjelaskan bahwa ciri kalimat pasif bahasa Jepang, ditandai dengan adanya verba dalam bentuk pasif, juga terdapat subjek yang dikenai suatu perbuatan. Ichikawa juga mengungkapkan bahwa kategori kalimat pasif tidak langsung ini termasuk cukup sulit untuk dipahami oleh pembelajar bahasa Jepang. Oleh karena itu, beliau menekankan perlu untuk memberikan pemahaman kepada pembelajar mengenai situasi bagaimana Jurnal Lingua Applicata Volume 2 Nomor 1 September 2018

Hal.81 
menggunakan kalimat pasif yang sebenarnya.

Lebih lanjut, Ichikawa (2005) mengungkapkan kesalahan-kesalahan yang dilakukan oleh pembelajar bahasa Jepang ketika membentuk kalimat pasif adalah: 1. Pembelajar sulit untuk mengubah bentuk verba ke dalam verba bentuk pasif bahasa Jepang dengan tepat; 2. Pembelajar sulit untuk menentukan objek pelaku dan subjek yang dikenai perbuatan; 3. Pembelajar sulit untuk menentukan partikel yang tepat bagi objek pelaku dan subjek yang dikenai perbuatan. Untuk penelitian ini, definisi kesalahan penggunaan dan pembentukan kalimat pasif dari Ichikawa (2005) digunakan untuk mencapai objektif penelitian.

\section{Metodologi Penelitian}

Penelitian ini menggunakan metode kuantitatif yang diadaptasi dari Brown, J. D dan Rodgers, T.S (2002). Metode kuantitatif ini dilakukan untuk menganalisis kesalahan dari segi kuantiti dan menyediakan statistik deskriptif untuk analisis kualitatif penelitian. Responden untuk penelitian ini adalah pembelajar bahasa Jepang dari mahasiswa Prodi Sastra Jepang, FIB, USU yang berada di semester 4. Hal ini dilakukan karena bentuk kalimat pasif bahasa Jepang telah diajarkan kepada mahasiswa tersebut pada awal semester 4. Responden diminta untuk menerjemahkan kalimat-kalimat bentuk pasif yang berbahasa Indonesia ke dalam kalimat pasif bahasa Jepang. Jumlah perkataan kalimat pasif dalam bahasa Indonesia sebanyak 200 perkataan dan pembelajar diminta untuk menerjemahkan kalimat pasif dalam bahasa Indonesia tersebut ke dalam bahasa Jepang. Terjemahan yang dihasilkan oleh responden dianalisis dengan mengaplikasikan kesalahankesalahan dalam membentuk kalimat pasif bahasa Jepang oleh Ichikawa (2005).

Analisis data dilakukan berdasarkan pernyataan dari Hamidi dan Baharuddin (2014), yang menyebutkan kegiatan menganalisis data dalam penelitian kuantitaif adalah:

1. Mengelompokkan Data

Berkaitan dengan pengkelasan kesalahan dalam penggunaan bahasa kedua, Dulay, Burt \& Krashen (1982) mengkelaskan kesalahan kepada 4 poin utama, yaitu: taksonomi linguistik, taksonomi strategi permukaan, taksonomi analisis komparatif dan Jurnal Lingua Applicata Volume 2 Nomor 1 September 2018 
taksonomi berdasarkan komunikasi. Pada taksonomi strategi permukaan, Dulay, Burt \& Krashen (1982), kemudian membagi kesalahan ke dalam empat kelas yaitu kesalahan pengurangan, kesalahan penambahan, kesalahan penyusunan, dan kesalahan pembentukan kata. Berdasarkan pada pembagian kelas kesalahan ini, hasil tes dari responden akan didata untuk kemudian dianalisis.

2. Menyajikan Data Setiap Variabel

$$
\text { Hasil dari data yang telah }
$$

dikumpulkan, kemudian dianalisis dan dipaparkan dengan menggunakan tabel dan grafik pai.

3. Melakukan Perhitungan dan Menjawab Perumusan Masalah

Hasil data yang disajikan melalui Tabel dan grafik Pai akan dipaparkan dan dijelaskan untuk menjawab perumusan masalah penelitian.

4. Melakukan Perhitungan untuk Uji Hipotesis yang telah Dilakukan

Hasil data yang terkumpul dianalisis dan diuji untuk menjawab dugaan dari penyebab timbulnya permasalahan dalam penelitian ini.

\section{Hasil dan Pembahasan}

Berdasarkan hasil analisis data, secara keseluruhan didapati sebanyak 620 kesalahan yang dilakukan pembelajar bahasa Jepang dalam menerjemahkan kalimat pasif berbahasa Indonesia ke dalam bahasa Jepang. Kesalahan yang terjadi berupa kesalahan dalam pemilihan dan pembentukan verba, noun, partikel, adjektiva, dan adverbial.

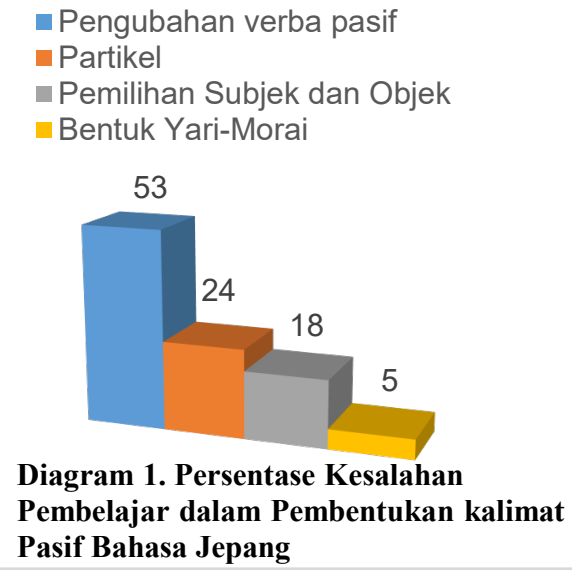

Diagram 1. Persentase Kesalahan

Pembelajar dalam Pembentukan kalimat

Pasif Bahasa Jepang

Sebagaimana terlihat pada Diagram 1. dapat diketahui bahwa persentase kesalahan dalam mengubah verba biasa bahasa Jepang ke dalam verba bentuk pasif ( rareru), menempati posisi persentase kesalahan tertinggi dibandingkan kategori kesalahan lainnya, yaitu sebanyak $53 \%$. Sedangkan kesalahan dalam pemilihan partikel yang tepat menduduki peringkat kedua dengan persentase sebanyak 24\%. Berikutnya, sebanyak $18 \%$ merupakan jenis kesalahan yang dilakukan oleh pembelajar dalam 
memilih objek pelaku dan subjek yang dikenai perbuatan. Dan akhirnya, kesalahan dalam membentuk kalimat yari-morai (memberi-menerima) diketahui juga menjadi jenis kesalahan yang paling sedikit dilakukan dengan pesentase $5 \%$.

Berikutnya, akan dipaparkan mengenai contoh-contoh kesalahan kalimat pasif yang dibuat oleh pembelajar yang kemudian dikategorikan ke dalam jenis-jenis kesalahan dalam pembentukan kalimat pasif bahasa Jepang yang dikemukakan oleh Ichikawa (2005).

\section{Kesalahan pada Pengubahan Verba Bentuk Pasif Bahasa Jepang}

Tabel (1) berikut memaparkan contoh-contoh kalimat pasif bahasa Jepang yang dihasilkan oleh pembelajar ketika mereka diminta untuk menerjemahkan kalimat pasif bahasa Indonesia ke dalam kalimat pasif bahasa Jepang. Tetapi, kalimat terjemahan yang dibuat oleh pembelajar ini tidak sesuai dengan aturan pembentukan verba bentuk pasif bahasa Jepang hingga dikategorikan ke dalam kalimat yang salah.
Tabel 1. Contoh Kalimat Kesalahan pada

Pengubahan Bentuk Kata Kerja Pasif

\begin{tabular}{|c|c|c|c|}
\hline No & $\begin{array}{c}\text { Kalimat } \\
\text { bahasa } \\
\text { Indonesia }\end{array}$ & & $\begin{array}{c}\text { Contoh kalimat } \\
\text { bahasa Jepang } \\
\text { terjemahan } \\
\text { pembelajar }\end{array}$ \\
\hline \multirow{2}{*}{1} & \multirow{2}{*}{$\begin{array}{l}\text { Ketika hasil } \\
\text { ujian bagus, } \\
\text { saya dipuji } \\
\text { oleh guru }\end{array}$} & 1 & $\begin{array}{l}\text { *shiken ga } \\
\text { yoitoki, sensei ni } \\
\text { homaremashita. }\end{array}$ \\
\hline & & 2 & $\begin{array}{l}\text { *watashi no } \\
\text { tomodachi ni } \\
\text { homesasemasu. }\end{array}$ \\
\hline \multirow[b]{2}{*}{2} & \multirow{2}{*}{$\begin{array}{l}\text { Saya pernah } \\
\text { dibuli kawan }\end{array}$} & 1 & $\begin{array}{l}\text { *watashi wa } \\
\text { tomodachi ni } \\
\text { ijimaremasita. }\end{array}$ \\
\hline & & 2 & $\begin{array}{l}\text { *watashi wa } \\
\text { tomodachi ni } \\
\text { ijimesareta ga } \\
\text { arimasu. }\end{array}$ \\
\hline \multirow{2}{*}{3} & \multirow{2}{*}{$\begin{array}{c}\text { Sekarang, mie } \\
\text { instan } \\
\text { dikonsumsi di } \\
\text { seluruh dunia }\end{array}$} & 1 & $\begin{array}{l}\text { *Ima wa, isutanto } \\
\text { ramen wa sekai o } \\
\text { taberemashita. }\end{array}$ \\
\hline & & 2 & $\begin{array}{l}\text { *ima, ramen wa } \\
\text { itten banjoo o } \\
\text { tabesasemasu. }\end{array}$ \\
\hline
\end{tabular}

Sumber: Data Penelitian 2017

Berdasarkan Tabel (1), dapat diketahui bahwa pembelajar melakukan kesalahan untuk mengubah bentuk verba pasif bahasa Jepang dengan tepat. Pembelajar terlihat bingung untuk membedakan antara verba pasif bahasa Jepang yang seyogyanya menggunakan bentuk rareru dengan verba bentuk shieki (kausatif) yang menggunakan bentuk saseru dan bentuk shieki-ukemi, dengan bentuk saserareru. Sebagaimana terlihat pada contoh kalimat (no.1.1), pembelajar membuat kalimat shiken ga yoi toki, sensei ni homaremashita. 
Pembentukan verba pasif homaremashita tidak sesuai dengan aturan pembentukan verba pasif bahasa Jepang yang tepat.

Hal ini disebabkan oleh bentuk verba pasif yang tepat untuk verba homemasu (memuji) adalah homeraremasu (dipuji). Hingga kalimat terjemahan untuk no.1 menjadi shiken ni yoi ten o totteitara, sensei ni homeraremashita.

Sedangkan untuk contoh kalimat (no.2.1), diketahui pembelajar gagal untuk mengubah verba ijimemasu (buli) ke dalam bentuk verba pasif yang tepat, ijimeraremasu (dibuli). Hingga kalimat terjemahan untuk no.2 menjadi watashi wa tomodachi ni ijimerareta koto ga arimasu.

Demikian juga halnya untuk kalimat (no.3.2), pembelajar menghasilkan kalimat ima wa, ramen wa itten banjo o tabesasemasu. Bentuk verba tabesasemasu (menyuruh makan) bukanlah bentuk verba pasif, melainkan verba bentuk shieki (kausatif). Sedangkan bentuk pasif yang tepat dari verba tabemasu adalah taberaremasu (dimakan). Adapun terjemahan untuk kalimat no.3 adalah genzai, insutanto ramen wa sekaijyuu de taberarete imasu.

Berdasarkan kesalahan-kesalahan yang dilakukan oleh pembelajar dalam mengubah bentuk verba pasif bahasa
Jepang yang tepat ini menggambarkan bahwa mereka tidak memahami bagaimana untuk mengubah bentuk verba pasif bahasa Jepang dengan tepat. Pembelajar cenderung bingung untuk membedakan yang mana bentuk verba pasif, dan bentuk verba kausatif (shieki), ataupun bentuk verba pasif-kausatif (shieki-ukemi). Kurangnya pemahaman dan kurangnya latihan penerapan mengenai cara mengubah verba pasif bahasa Jepang, diduga menjadi penyebab kesalahan ini terjadi.

\section{Kesalahan pada Pemilihan Partikel}

Tabel (2) berikut menunjukkan contoh kesalahan kalimat pembelajar dalam memilih partikel yang tepat ketika membentuk kalimat pasif bahasa Jepang.

Berdasarkan Tabel (2) Kesalahan Terjemahan Bahasa Indonesia dalam Partikel Bahasa Jepang, pada contoh kalimat pembelajar, (no.1.1), dapat diketahui bahwa pembelajar tidak dapat melengkapi kalimat pasif tersebut dengan memilih partikel yang tepat. Pembelajar menggunakan partikel ga dan ni untuk menghubungkan subjek kalimat dan objek pelaku. Sedangkan partikel yang sesuai untuk kalimat ini adalah wa dan ni yotte, hingga kalimat ini seharusnya, denwa wa Beeru ni yotte hatsumeisaremashita. 
Tabel 2. Contoh Kesalahan Terjemahan Bahasa Indonesia dalam Partikel Bahasa Jepang

\begin{tabular}{|c|l|l|l|}
\hline No & $\begin{array}{l}\text { Kalimat } \\
\text { bahasa } \\
\text { Indonesia }\end{array}$ & \multicolumn{2}{|l|}{ Kalimat bahasa Jepang } \\
\hline \hline \multirow{2}{*}{1} & $\begin{array}{l}\text { Telepon } \\
\text { ditemukan } \\
\text { oleh Bell }\end{array}$ & 1 & $\begin{array}{l}\text { *Denwa ga Berru ni } \\
\text { hatsumeisaremashi } \\
\text { ta. }\end{array}$ \\
\cline { 2 - 4 } & 2 & $\begin{array}{l}\text { *Beru ga denwa o } \\
\text { hatsumeisaremashi } \\
\text { ta. }\end{array}$ \\
\hline \multirow{2}{*}{2} & $\begin{array}{l}\text { Ketika } \\
\text { pulang dari } \\
\text { sekolah, } \\
\text { saya } \\
\text { kehujanan }\end{array}$ & 1 & $\begin{array}{l}\text { *Gakko e kaetta } \\
\text { toki, watashi ni } \\
\text { ame o futte } \\
\text { moraimashita. }\end{array}$ \\
\cline { 2 - 4 } & 2 & $\begin{array}{l}\text { *Gakkou e kaeta } \\
\text { toki, ame ga } \\
\text { shimaishita. }\end{array}$ \\
\hline
\end{tabular}

Sumber: Data Penelitian 2017

Demikian juga halnya dengan contoh kalimat (no.2), selain kesalahan dalam memilih partikel yang tepat, pembelajar juga gagal untuk menerjemahkan kata 'kehujanan' ke dalam bahasa Jepang. Untuk menerjemahkan kata 'saya kehujanan', pembelajar menggunakan watashi wa ame o futte moraimashita dan ame ga shimaimashita. Sedangkan penerjemahan yang tepat untuk kata 'saya kehujanan' adalah watashi wa ame ni furaremashita.

Berdasarkan kesalahan-kesalahan dalam pemilihan partikel yang tepat dan penerjemahan kalimat pasif bahasa Indonesia ke dalam bahasa Jepang di atas menunjukkan bahawa pembelajar tidak memahami aturan penggunaan dan pembentukan kalimat pasif bahasa Jepang yang tepat. Pembelajar cenderung menerjemahkan langsung kata per kata dari bahasa sumber ke dalam bahasa target, tetapi mengabaikan peraturan penggunaan tata bahasa di dalam bahasa Jepang yang menyebabkan kesalahan terjadi. Kesalahan ini terjadi karena adanya kecenderungan negatif transfer dan generalisasi terhadap aturan pembentukan kalimat pasif bahasa Jepang.

\section{Kesalahan dalam Meyusun Subjek dan}

\section{Objek Pelaku}

Tabel (3) berikut menunjukkan contoh kalimat kesalahan yang dilakukan oleh pembelajar dalam menyusun subjek dan objek pelaku pada kalimat pasif bahasa Jepang. Berdasarkan Tabel (3), dapat diketahui bahwa pembelajar tidak mengikuti aturan penyusunan subjek dan objek pelaku yang benar di dalam pembentukan kalimat pasif bahasa Jepang. Seperti terlihat pada contoh kalimat (no.1.1) dan (no.1.2), kedua kalimat pembelajar tersebut menunjukkan kesalahan dalam penyusunan subjek dan objek pelaku. Kedua kalimat pembelajar tersebut menggunakan ryoushin (orang tua) sebagai subjek dan watashi (saya) sebagai objek pelaku. Sedangkan penyusunan Jurnal Lingua Applicata Volume 2 Nomor 1 September 2018 
yang sesuai dengan aturan pembentukan kalimat pasif bahasa Jepang yang tepat untuk kalimat (no.1) adalah watashi wa ryoushin ni aisaremashita (saya dicintai oleh orang tua saya).

Tabel 3. Contoh Kalimat Kesalahan dalam Menyusun Subjek dan Objek Pelaku

\begin{tabular}{|c|l|l|l|}
\hline No & $\begin{array}{c}\text { Kalimat } \\
\text { bahasa } \\
\text { Indonesia }\end{array}$ & \multicolumn{2}{|c|}{$\begin{array}{c}\text { Kalimat bahasa } \\
\text { Jepang }\end{array}$} \\
\hline \hline 1 & $\begin{array}{l}\text { Saya disayangi } \\
\text { oleh kedua } \\
\text { orang tua } \\
\text { saya }\end{array}$ & 1 & $\begin{array}{l}\text { * ryoushin wa } \\
\text { watashi ni } \\
\text { aishimasu. }\end{array}$ \\
\cline { 2 - 4 } 2 & 2 & $\begin{array}{l}\text { *youshin wa } \\
\text { watashi ni } \\
\text { aisarete imasu. }\end{array}$ \\
\hline & $\begin{array}{l}\text { Diari saya } \\
\text { kawail oleh }\end{array}$ & 1 & $\begin{array}{l}\text { *watashino } \\
\text { diari- o } \\
\text { torasaremashita. }\end{array}$ \\
\cline { 2 - 4 } & 2 & $\begin{array}{l}\text { *watashi no } \\
\text { nikki ga } \\
\text { totteitta. }\end{array}$ \\
\hline
\end{tabular}

Sumber: Data Penelitian 2017

Pada contoh kalimat (no.2.1) dan (no2.2), dapat diketahui bahwa selain gagal untuk menentukan subjek dan objek pelaku pada kalimat pasif bahasa Jepang, pembelajar juga melakukan kesalahan untuk mengubah bentuk verba pasif bahasa Jepang yang tepat, yaitu: watashi no diari- o torasaremashita. Pembelajar cenderung menerjemahkan langsung kata per kata dari bahasa Indonesia ke dalam bahasa Jepang, juga tidak memperhatikan pola susunan pembentukan kalimat pasif bahasa Jepang. Semestinya pembelajar menyusun kalimat ini menjadi watashi wa tomodachi ni nikki o toraremashita (diari saya diambil oleh teman). Kesalahankesalahan pada contoh kalimat (no.1) dan (no.2) ini terjadi, diduga disebabkan oleh kurangnya pemahaman dan kurangnya latihan-latihan pembelajar dalam menggunakan kalimat pasif bahasa Jepang.

\section{Kesalahan Penggunaan Antara Verba} Pasif ( rareru) dan Penggunaan YariMorai (Memberi-menerima)

Tabel (4) berikut menunjukkan contoh kesalahan kalimat pembelajar dalam membentuk dan memilih antara verba pasif bahasa Jepang ( rareru) dengan kalimat Yari-Morai (memberimenerima). Sebenarnya, kalimat YariMorai berbeda dengan kalimat pasif ( rareru). Seyogyanya, kalimat Yari-Morai digunakan untuk menunjukkan ungkapan rasa terima kasih subjek untuk jasa ataupun pemberian yang dia terima.

Tabel 4. Contoh Kesalahan Penggunaan Antara Verba Pasif ( rareru) dan Penggunaan Yari-Morai (Memberimenerima)

\begin{tabular}{|c|l|c|l|}
\hline No & \multicolumn{1}{|c|}{$\begin{array}{c}\text { Kalimat } \\
\text { bahasa } \\
\text { Indonesia }\end{array}$} & \multicolumn{1}{|c|}{$\begin{array}{c}\text { Contoh kalimat } \\
\text { Kesalahan Yari- } \\
\text { Morai }\end{array}$} \\
\hline \hline 1 & $\begin{array}{l}\text { Saya } \\
\text { dibelikan }\end{array}$ & 1 & $\begin{array}{l}\text { *watashi wa } \\
\text { chichi ni okashi o } \\
\text { kawaremashita. }\end{array}$ \\
\hline
\end{tabular}




\begin{tabular}{|c|c|c|c|}
\hline & $\begin{array}{l}\text { mainan oleh } \\
\text { ayah }\end{array}$ & 2 & $\begin{array}{l}\text { *watashi wa } \\
\text { itsumo no } \\
\text { chichioya ni } \\
\text { omocha o } \\
\text { ataeraremashita. }\end{array}$ \\
\hline \multirow{2}{*}{2} & \multirow{2}{*}{$\begin{array}{l}\text { Ibu } \\
\text { membuatkan } \\
\text { saya sup } \\
\text { yang pedas }\end{array}$} & 1 & $\begin{array}{l}\text { *haha wa watashi } \\
\text { ni oishii no sup o } \\
\text { tsukuraremasita. }\end{array}$ \\
\hline & & 2 & $\begin{array}{l}\text { *okaasan wa } \\
\text { suupu no oishii o } \\
\text { tsukuraremashita. }\end{array}$ \\
\hline \multirow[b]{2}{*}{3} & \multirow{2}{*}{$\begin{array}{l}\text { Guru } \\
\text { mengajarkan } \\
\text { saya banyak } \\
\text { ilmu }\end{array}$} & 1 & $\begin{array}{l}\text { *sensei ni oshiete } \\
\text { takusan } \\
\text { moraimashita. }\end{array}$ \\
\hline & & 2 & $\begin{array}{l}\text { *sensei wa } \\
\text { watashi ni } \\
\text { takusan ga } \\
\text { chishiki o } \\
\text { oshierareta. }\end{array}$ \\
\hline
\end{tabular}

Sumber: Data Penelitian 2017

Berdasarkan contoh kalimat pembelajar pada Tabel (4), terlihat bahwa pembelajar terpengaruh dengan awalan di dan akhiran -kan, pada kalimat bahasa Indonesia dan menggunakan bentuk kalimat pasif bahasa Jepang sebagai penerjemahan kalimat bahasa Indonesia tersebut. Hal ini tentu saja mengakibatkan kalimat terjemahan pembelajar tersebut terdengar aneh di dalam bahasa Jepang. Kalimat bahasa Indonesia (no.1, 2, dan 3) menunjukkan rasa terima kasih subjek terhadap ayah, ibu, dan gurunya terhadap pemberian atau jasa mereka. Tetapi, penerjemahan kalimat tersebut ke dalam bahasa Jepang dengan menggunakan kalimat pasif menyebabkan nuansa terima kasih tersebut menjadi hilang. Sebaliknya, kalimat dalam bahasa Jepang tersebut memberi kesan adanya perbuatan yang tidak meyenangkan yang diterima oleh subjek.

Oleh karena itu, untuk kalimat (no.1, 2, dan 3) semestinya menggunakan bentuk kalimat Yari-Morai, seperti: 1. Watashi wa chichi ni omocha o katte moraimashita. 2. Haha wa oishii ryouri o tsukutte kuremashita. 3. Sensei wa chishiki o oshiete kuremashita. Negatif transfer diduga menjadi penyebab kesalahan ini terjadi.

\section{Kesimpulan}

Secara keseluruhan, penelitian telah mengadaptasi definisi kesalahan pembentukan kalimat pasif bahasa Jepang oleh Ichikawa (2005). Berdasarkan hasil analisis data melalui kalimat-kalimat yang ditulis oleh pembelajar, bentuk-bentuk kesalahan dalam pembentukan kalimat pasif bahasa Jepang telah diidentifikasi.

Hasil penelitian menunjukkan bahwa pembelajar melakukan kesalahan dalam membentuk kalimat pasif bahasa Jepang yang sesuai dengan aturan penggunaannya.

Bentuk-bentuk kesalahan dalam membentuk kalimat pasif bahasa Jepang 
adalah: Pertama, pembelajar membuat kesalahan dalam mengubah bentuk verba pasif bahasa Jepang. Kurangnya pemahaman pembelajar dan kurangnya latihan bagaimana untuk mengubah verba bentuk pasif ini diduga menjadi penyebab timbulnya kesalahan.

Kedua, kesalahan dalam memilih partikel yang tepat juga menjadi faktor penyebab kesalahan terjadi dalam membentuk kalimat pasif bahasa Jepang. Pembelajar tidak memahami dengan baik aturan pembentukan kalimat pasif bahasa Jepang dan cenderung membuat generalisasi berlebih terhadap patikel yang umum digunakan pada kalimat pasif bahasa Jepang.

Berikutnya, kesalahan dalam menyusun subjek dan objek pelaku di dalam kalimat pasif bahasa Jepang juga menjadi bentuk kesalahan pembelajar dalam mengaplikasikan kalimat pasif tersebut.

Kecenderungan

menerjemahkan langsung kata per kata bahasa Indonesia ke dalam bahasa Jepang menyebabkan timbulnya negatif transfer.

Hal ini sesuai dengan pernyataan yang diungkapkan oleh Odlin (1998), yaitu negatif transfer cenderung akan terjadi di dalam pembelajaran bahasa asing ketika sistem aturan tata bahasa di antara bahasa ibu dan bahasa target berbeda ataupun tidak sama, tetapi, pembelajar cenderung mengaplikasikan sistem aturan tata bahasa pada bahasa ibunya ketika menggunakan bahasa target.

Akhirnya, kurangnya pemahaman pembelajar mengenai bentuk verba pasif bahasa Jepang dan sistem aturan pembentukan kalimat pasif bahasa Jepang menyebabkan mereka cenderung berfikir bahwa setiap verba bahasa Indonesia yang mempunyai awalan di-, bila diterjemahkan ke dalam bahasa Jepang semestinya menjadi verba pasif rareru. Sehingga, adanya verba bahasa Indonesia yang berawalan -di dan juga mempunyai akhiran -kan, seperti kata 'dibelikan’ dianggap juga sebagai verba pasif di dalam bahasa Jepang. Hal ini menyebabkan pembelajar keliru dengan bentuk verba Yari-morai yaitu ungkapan yang menunjukkan rasa terima kasih terhadap jasa, bantuan orang lain.

Melalui hasil analisis penelitian ini, diharapkan pembelajaran bahasa Jepang di Indonesia dapat ditingkatkan, khususnya terkait pembelajaran kalimat pasif bahasa Jepang. Perlunya latihan yang berkesinambungan berkenaan dengan cara mengubah verba pasif bahasa Jepang, dan cara membentuk kalimat pasif bahasa Jepang terhadap Jurnal Lingua Applicata Volume 2 Nomor 1 September 2018 
pembelajar sangat dianjurkan untuk membiasakan mereka dengan tata aturan pembentukan kalimat pasif bahasa Jepang yang benar.

Kemudian, hal yang semestinya juga menjadi perhatian bagi pengajar bahasa Jepang adalah untuk memfokuskan pengajaran pada perbedaan antara sistem aturan dalam bahasa Indonesia dan bahasa Jepang, serta menyadarkan pembelajar mengenai adanya perbedaan aturan penggunaan tata bahasa di antara kedua bahasa tersebut agar pembelajar berpikir lebih kritis dalam mengunakan bahasa Jepang.

Dengan itu, diharapkan pembelajar bahasa Jepang tidak melakukan generalisasi berlebih ketika mereka mengahadapi kesulitan mengaplikasikan bahasa Jepang disebabkan mereka sudah dapat merealisasikan apa yang telah biasa mereka pembelajari.

\section{Daftar Pustaka}

Brown, J. D, \& Rodgers, T. S. 2002. Doing Second Language Research. New York: Oxford University Press.

Dulay, H.C., Burt, M. \& Krashen, S. 1982. Language Two. New York: Oxford University Press.

Hama, Y. 2005. Indonesia kara rainichi shita shokyuu nihongogakushuusha ni okeru goyou bunseki $=$ Error analysis on Beginners Japanese Language Learners from Indonesia - Bachelor Thesis, Departement of Language Education, Faculty of International Studies. Obirin University. Japan.

Hamidi, A.S, \& Baharuddin, E. 2014. Metode Penelitian Kuantitatif Aplikasi dalam Pendidikan. Deepublish: Yogyakarta.

Haslina, H, Hasuria Che Omar. 2013. Asas Terjemahan dan Interpretasi. Pulau Pinang: Penerbit USM.

Harmer, J. 2001. The Practice of English Language Teaching. England: Pearson Education Limited.

Halim, Hazlina Abdul, Ang L. Y. 2017. Kesalahan Pemilihan dan Pembentukan kata dalam Terjemahan Bahasa Perancis. GEMA Online ${ }^{\circledR}$ Journal of Language Studies.15 (2), 151-164

Ichikawa, Y. 2005. Shokyuu nihongo bunpou to oshiekata no pointo $=$ Point of basic Japanese grammar and teaching. Japan: Surii ee network.

- 1997. Nihongo goyou youreibun kojiten = A dictionary of Japanese Errors. Tokyo: Bojinsha.

Moentaha, S. 2006. Bahasa dan Terjemahan. Jakarta: Kesaint Blanc

Odlin, T. 1993. Language Transfer-Cross Linguistic influence in Language. Learning, In Long, $M$ and Richards Jack (Eds.). New York: Cambridge University Press.

Ozeki, H. 2010. Nihongo o oshieru tame no dai ni gengogaku shutokuron nyuumon = An Introduction to Second Language Acquisition for Japanese Teaching. Japan: Kuroshio.

Risda, D. 2009. Kesalahan Penggunaan Ukemi dari Pembelajar bahasa Jepang, data diambil dari karangan Mahasiswa Indonesia. Jurnal Bahasa Jepang, Vol 1 No 1, 13-23. Bandung: ASPBJI \& The Japan Foundation Jakarta. Yoshikawa Taketo. 1982. Nihongo goyou bunseki: Japanese Error Analysis. Japan: Meiji Shoin. 